\title{
Morality, Justice, and Economic Theory of Crime: A Positive-Normative Analysis
}

\section{Felipe Coelho Sigrist, Solange Regina Marin}

Department of Economics and International Affairs at Universidade de Santa Catarina, Florianópolis, Brazil

Email: felipe_sigrist@yahoo.com.br

How to cite this paper: Sigrist, F. C., \& Marin, S. R. (2022). Morality, Justice, and Economic Theory of Crime: A Positive-Normative Analysis. Modern Economy, 13, 122. https://doi.org/10.4236/me.2022.131001

Received: November 8, 2021

Accepted: January 3, 2022

Published: January 6, 2022

Copyright $\odot 2022$ by author(s) and Scientific Research Publishing Inc. This work is licensed under the Creative Commons Attribution International License (CC BY 4.0).

http://creativecommons.org/licenses/by/4.0/

\section{(c) (i) Open Access}

\begin{abstract}
This paper aims to discuss some issues of morality and sense of justice present in the Economic Theory of Crime with the lens of the methodological positive and normative dichotomy in Economics. There has already been done some works describing the differences in positive and normative Law and Economics, but we believe that the Economics of Crime, considered as a topic inside Law and Economics, has some specific open and important debates that could be enlightened by the discussion of positive and normative economics. Through a literature review of critics of Economic Theory of Crime, we pointed out the main criticized topics and then use the positive-normative dichotomy in Law and Economics to analyze how those critics can be interpreted on both perspectives and how both perspectives are able (or not) to provide a complete and realistic interpretation of criminal behavior and law enforcement.
\end{abstract}

\section{Keywords}

Morality, Justice, Economic Theory of Crime, Positive-Normative Analysis

\section{Introduction}

The publication of the book "The Future of Law and Economics" by Calabresi (2016) brought light to some important debates that have been not receiving much attention by scholars of Law and Economics, namely the importance of values and norms when analyzing laws (or legal problems) with economic tools.

Economic Theory of Crime, as a branch of the Law and Economics movement, has also been neglecting those subjects since Gary Becker started this research agenda when published "Crime and Punishment. An Economic Approach" in 1968. However, when we discuss legal problems (as a whole) these questions are of great importance, when discussing criminality the relevance is even 
larger.

Traditionally, Economic Theory of Crime has treated any form of violation similarly, i.e., without taking into account the existence of violations that belong to the civil sphere and others that belong to the criminal sphere. As some authors argue (Coffee Jr, 1991; Dau-Schmidt, 1990; Drane \& Neal, 1980), the existence of this differentiation is not unjustified: torts (violations inside civil sphere) are those which cause harms to a single individual, while crimes (violations inside criminal sphere) consist on those felonies which trespass some moral norms from the society. Additionally, Economic Theory of Crime treats punishment on a utilitarian basis, i.e., that the usage of punishment against others individuals is justified as long as it avoids a greater evil. Finally, Law and Economics has a particular approach to the goal of the justice system, which is allocative efficiency (and for some cases utility maximization).

All three of these topics, which make up the core of what is discussed throughout this paper, raise questions that require debates on both morality and values, if they are to be understood in their entirety. Besides raising the main arguments existing in the Law and Economics debate regarding these topics, this article brings as a novelty the use of positive-normative analysis (Wade Hands, 2012; Weston, 1994) as a tool capable of bringing new questions to the debate.

The paper is composed of this introduction and three more sections. In the second chapter, we present the three main topics that are going to be discussed in the paper concerning morality and justice, which are: 1) does the benefits of the criminal activity must be considered positively in the calculus of the social welfare; 2) how is understood the use of punishment inside Economic Theory of Crime; and 3) what is the objective of the Justice System in the same theory? In the third chapter, we describe the positive-normative dichotomy inside the Law and Economics literature. Positive Law and Economics is concerned with incentives and opportunities that the laws have upon the agents, while normative approach is interested in correcting market failures through legal intervention. Narrowing our positive-normative analysis to Economic Theory of Crime, the positive analysis aims to understand how criminal behavior responds to changes in costs and benefits related to criminal activities, while the normative analysis defends that the criminal law serves to impose additional costs to those activities perceived as illegal, minimizing the social costs of the activity, and providing incentives to deter non-economic losses. In the last section, we provide some final comments on the subjects, and also put forward a discussion about how other disciplines (in special Law) understand the role of Economic Theory of Crime, based on the positive-normative distinction.

\section{Crime, Morality and Justice}

In this section we present the three main points, within the Economic Theory of Crime, which will be discussed throughout this paper. The choice of these three 
topics is the result of a literature review of questions made by other areas of knowledge, especially Law, about theoretical aspects present in the Economic Theory of Crime. In the first subsection, we discuss the moral problem that exists in adding the gains obtained through criminal activity as a positive utility in the social welfare function. In the second subsection, we discuss the importance attributed to punishment within the Economic Theory of Crime (punishment as a deterrent) and how other approaches to the use of punishment find problems in the interpretation offered by economists. Finally, in the third subsection, we discuss the purpose of the Criminal Justice System from an economic perspective. As usual, economics apply efficiency criteria to Criminal Justice System. However, it is not quiet obvious, as some economists sees it, that the purpose of Criminal Justice System should be achieving efficiency.

\subsection{Issue on Morality}

The optimum law enforcement model used by economists, developed by Becker (1968), starts from an expected utility function that can be written as:

$$
E U=p U(b-f)+(1-p) U(b),
$$

where $p$ is the probability of capture and punishment, $U$ is utility, $E U$ is expected utility, $b$ is income if undetected, and $b-f$ income if punished. All incomes include psychic components such as fear, excitement, pain which are assumed to be convertible to monetary equivalents (Garoupa, 1997: p. 268).

Departing from this equation, the two main variables that causes criminal deterrence are $p$ and $f$. Becker (1968) considers the fine as a simple income transfer (or in case of sanctions the costs of raising them are null), so the only variable that is costly to enforce is the probability of apprehension. The welfare function, as traditionally employed in economics, represents the aggregation of all individuals utilities. From (1), risk-neutral individuals commit an offense if, and only if, $b>p f$, so the social utility is:

$$
W=\int_{0}^{H} \int_{p(c) f}^{B}(b-h) g(b, h) \mathrm{d} b \mathrm{~d} h-c,
$$

where $W$ is the social welfare function; $h$ is the harm caused, and lies in the interval $[0, H] ; b$ is the criminals benefit, and lies in the interval $[0, B] ; f$ is the fine/sanction choosed by the social planner; and $c$ is the expenditure in detection and conviction, so that $p(c)$ is the probability of the criminal being arrested. Social welfare is calculated adding the criminals benefit less the harm caused to the victims less the enforcement costs (Garoupa, 1997: p. 269). Therefore, the marginal cost of enforcement must equal the marginal harm caused to the victim plus the marginal benefit of the criminal.

The first issue discussed in this paper derives from the way welfare function is calculated, i.e., does the benefit of the criminal activity must be considered positively in the calculus of the social welfare? Stigler (1970) was the first author to question the existence of a "social value of the gain to offenders" arguing: 
[...] what evidence is there that society sets a positive value upon the utility derived from a murder, rape, or arson? In fact the society has branded the utility derived from such activities as illicit. It may be that in a few offenses some gain to the offender is viewed as a gain to society, but such social gains seem too infrequent, small, and capricious to put an effective limitation upon the size of punishments (Stigler, 1970: p. 527).

For Veljanovski (1980) and Barnes (1998) the problem of existing a supposedly social gain from crime arises from the attempt to create a general theory of illegal activity, which makes Economic Theory of Crime to treat Tort Law and Criminal Law in a same manner. According to Barnes (1998), the existence of this differentiation inside law is not unjustified. Illegal behaviors inside tort law can result in some sort of social benefit, although creates negative externalities and for those cases, the punishment (product of probability and fine) can be understood as the price for committing an illegality, as proposed in Economic Theory of Crime.

On the other hand, when referring to behaviors considered illegal inside criminal law, it is understood that those actions are socially unwanted, and therefore, no social gain can be derived from them. Additionally, the very idea of punishment being the price to commit an illegal action becomes controversy when applied to hideous crimes as rape or murder. Is there any price socially accepted that when paid justifies the occurrence of these hideous crimes? Some behaviors are considered so immoral that even if the perpetrator is willing to pay its price to commit it, that behavior still is considered to be unwanted by the society (Gibbons, 1982: p. 184).

Cooter (1984: p. 1523) points that: "economic perspective is blind to the distinctively normative aspect of law, viewing a sanction for doing what is forbidden merely as the price of doing what is permitted"; and continues: "officials should create prices to compel decision makers to take into account the external costs of their acts, whereas officials should impose sanctions to deter people from doing what is wrong."

Coffee Jr (1991) defends that what mostly distinguishes the criminal law (from Tort Law) is its operation as a system of moral education and socialization. Acts are perceived as criminal because they violated existing moral values inside a society, while tortious acts involve only private interests. Tort law seeks to balance private benefits and public costs. Criminal law, on the other hand, does not because balancing would undercut the moral rhetoric of the criminal law. In this sense, criminal law is a system for public communication of values.

Becker (1968) never intended to propose an economic definition for crime (or an economic justification to consider an action criminal or illegal). He only assumed that are some behaviors labeled as illegal and based on costs and benefits, individuals decide to perform those acts or comply to the law. Further authors, ${ }^{1}$ Formally, Cooter (1984) defines sanctions as: "a detriment imposed for doing what is forbidden" and price as: "a payment of money which is required to do what is permitted". 
Calabresi and Melamed $(1972)^{2}$, Posner $(1985)^{3}$, and Klevorick (1985) ${ }^{4}$, had proposed economic definitions to crime, but neither had brought into attention the importance of this differentiation.

Even narrowing the scope of our analysis only to Criminal Law the generalization of all sorts of crimes is problematic for Economic Theory of Crime. It is easier accepting that a theft is only a wealth transfer, and therefore does not impose additional cost to the society-so the sanction imposed to this felony can be seen as a price. However, the same can hardly be said to hideous crimes. For those felonies, the equivalence between criminal gains and victims harms it is not so straight forward as proposed by Economic Theory of Crime (Barnes, 1998; McChesney, 1993). Additionally, there is an inherent difficulty in developing a hierarchy of harms that would indicate which harmful acts are to be considered as criminal and which are treated as tortious (Drane \& Neal, 1980).

The first economic analysis that provided a justification for the differentiation of criminal law and tort law was presented in Dau-Schmidt (1990). For the author, tort law must be used, as commonly used by economists, as an opportunity-shaping policy which gives incentives to individuals to act in a desired way, while criminal law must be used as a preference-shaping policy, which intents to increase the taste of individuals to a desired behavior. As torts produces negative externalities, laws should be designed to shape the opportunities sets so only actions whose benefits exceeds externalities are performed. Crimes are considered to be socially unwanted, so laws should be designed to shape individuals tastes and values so those behaviors labeled as "criminal" receive a lower position in the individuals ordering preferences.

As we discuss in Section 3, economists tend to take for granted individuals tastes (values) and hardly accept the possibility of changes on those tastes ${ }^{5}$. The main reason for this rejection, according to Dau-Schmidt (1990: p. 16), is because both "Pareto optimal and social welfare criteria are based on individual preferences. Allowing individual preferences to change undermines the basis for these criteria".

\subsection{Usage of Punishment in Economic Theory of Crime}

The second topic refers to the use of punishment within the Economic Theory of Crime. One of the fundamental pillars of the defense of economists for the usage of punishments in the justice system is the belief that they are capable of deter${ }^{2}$ For Calabresi and Melamed (1972) particular acts are distinguished as crimes, for which special sanctions are imposed, because society needs to prevent individuals from changing property rules and inalienability rules into liability rules at their individual discretion.

${ }^{3}$ For Posner (1985) criminal sanction is used to induce individuals to engage in voluntary rather than coercitive transaction (market bypass) with one another when voluntary ones are feasible at low enough cost.

${ }^{4}$ For Klevorick (1985) "an act is a crime because the actor violates the transaction structure that society established". "The criminal sanction is employed to enforce the transaction structure that society has chosen as well as to charge the offending actor for the harms that his action imposes on individuals within the society" [p. 908].

${ }^{5}$ See Stigler and Becker (1977). 
ring criminal practice. However, this idea of punishment as a deterrent is not a novelty offered by economics, since utilitarian authors from the 17 th and 18 th centuries, who had criminality as their subject of study, already pointed to this possible benefit of punishment (Gibbons, 1982).

Inside punishment as deterrence approach, it is accepted that the use of punishments is a justifiable evil only if it is able to reduce or prevent the occurrence of a greater evil. The punitive practice must have some social utility, in this case, to prevent those who committed a violation to repeat it, and also serving as an example so others do not violate (Bittner \& Platt, 1966).

Another approach on modern debate about the use of punishment is the principle of retribution, whose origin refers to the philosophical idealism tradition. For the punishment as retribution approach, an individual deserves to be punished only if he violated some moral norm of society, such that punishment would serve as a form to reestablish the "moral imbalance" caused by the violation. Therefore, only those who have been proven to violate any morality deserve to be punished, and the punishment of innocents is considered highly immoral. Additionally, the punishment must be proportionate to the violation committed, i.e., the punishment cannot exceed the damage caused (McCloskey, 1965).

Under retributive theory, there are two problems with the way Economic Theory of Crime prescribes the application of punishments. First, the occurrence of sentencing is probabilistic and there may be a Type I error (a guilty person being acquitted) or a Type II error (an innocent person being sentenced). Both are unwanted under retribution, either because he who violated a norm must be punished so the balance of morality can return, or because of the immorality, mentioned above, of punishing an innocent person. Second, in economic studies, punishment results from the multiplication of the severity of the penalty applied with the probability of this penalty being, in fact, applied, while the retributive punishment, whose probability of application on those who committed a violation must equal one, is measured only by severity of the penalty applied. In both situations the optimal punishment must equal the harm caused by the one who is been punished. However, the assumption made by economists that the cost of raising the probability of punishment is greater than the cost of raising the severity leads to the conclusion that the optimal enforcement of the law must be made by raising the severity to its maximum, which in the retributive perspective would be considered highly unfair (Barnes, 1998).

Ehrlich (1982), for instance, raises the possibility that society may suffer desutility from the punishment of innocents, so minimizing this error may be socially wanted. The first consequence of adopting such a policy that comes in mind, perhaps only to economists, is the considerable increase in the costs of the criminal justice system. About raising fines or sanctions to the highest feasible level, it can be argued that Economic Theory of Crime admits an idea of marginal deterrence, i.e., that it is efficient to punish less harmful crimes with lighter penalties, in order to generate incentives so that more severe crimes are not committed. However, it is possible to practice a marginal deterrence policy raising fines 
or sanctions to their highest levels and adjusting total punishment through the probability of punishment (Posner, 1985).

In practice, a society that uses punishment as a deterrent would not need to apply the punishment itself, since the punishments are included in the calculation of the utility of the person who intends to commit a crime as an expected cost (ex ante cost), so it is the fear of being punished, and not the punishment itself, which causes deterrence. However, failure to apply punishments would lead to a loss of credibility in law enforcement. As Andenaes (1970: p. 652) states: "The aim of application of punishment is to fulfill the command of the law so that it does not contradict itself".

Finally, one last problem about how Economic Theory of Crime deals with punishment is commensurability. Economic models of optimal law enforcement use monetary measures for both pecuniary (fines) and non-pecuniary (prisons) penalties. In order to measure monetarily non-pecuniary penalties, most authors only considers imprisonment costs whose monetaries equivalents are straightforward, as future earning in the legal market, or the prisional system costs itself (those imposed on the society). However, when we think about the costs of being imprisoned, especially those imposed on the inmate, comes in mind problems like poor life quality, mobility and liberty deprivation, and others problems which are hard to measure monetarily. Also, how can punishment be interpreted as the price for committing a crime if it cannot be measured?

\subsection{The Purpose of Criminal Justice}

In this section, we discuss the concepts of justice inside Economic Theory of Crime. Models of optimal law enforcement consider that the goal of criminal justice system is to achieve allocative efficiency or to maximize social welfare. Allocative efficiency is achieved through the concept of Pareto optimality, which is a useful tool because allows limits comparisons among different states of society without requiring interpersonal comparisons of utility (Dau-Schmidt, 1990: p. 6). Social welfare maximization, on the other hand, is a necessary criteria because Pareto optimality does not specify a unique optimal state for society ${ }^{6}$. For each possible initial assets distribution or individuals preferences a different $\mathrm{Pa}$ reto optimal can be achieved. To choose among the different possible Pareto optimal states, economists hypothesize a social preference ordering in which a society ranks each possible state of society from least to most preferred (Dau-Schmidt, 1990: p. 7).

To maximize social welfare, policy makers must choose values for the probability and severity of punishments so the social cost of crime and law enforcement costs are minimized. According to Ehrlich (1982: p. 6), the three social losses resulting from crimes that ought to be minimized are: 1) the direct social damage from offenses defined as the income loss to victims from the occurrence of crime over the net income gains to offenders; 2) the direct cost of enforce-

${ }^{6}$ The specification of the Pareto optimality for a society depends on the initial distribution of assets in that society and the preferences held by its members (Dau-Schmidt, 1990). 
ment in terms of apprehending and convicting offenders; and 3) the social costs resulting from the subsequent sanctions or other treatment imposed on convicted offenders.

Some questions raised at the first section, such as the inclusion of criminal gains in the calculation of social welfare, raise some doubts about the desirability of the criminal justice system to be based on a social welfare maximizing criteria. Posner (1979), for instance, rejects the social welfare maximization criteria, suggesting that wealth maximization should be the goal. Since maximizing social welfare involves ethical questions about "what is best for society" or "all sorts of preferences should be considered in social welfare calculus", questions that Posner sees as unsettled, the best criteria for justice (a value-free criteria) is justice as allocative efficiency.

Advancing the argument of wealth maximization, Posner (1980) defends the use of Kaldor-Hicks efficiency criteria instead of Pareto. Since a situation of Kaldor-Hicks optimality occurs when the "increase in value be sufficiently large that the losers could be fully compensated (by the winners)". The Kaldor-Hicks efficiency (or wealth maximization) completely avoids interpersonal comparison of utilities, because there is no way of knowing "whether the utility to the winners of not having to pay compensation will exceed the disutility of losers of not receiving compensation" (Posner, 1980: p. 491).

Some authors also explores some different concepts of justice, specifically, justice as fairness. Ehrlich (1982) discusses the possibility of the justice system being an ex post equity promoter. A relatively consolidated fact in the economic literature of crime is that the frequency of most crimes tends to increase along with the level of inequality in a population, whether due to the decrease in the opportunity cost of the poorest or the increase in available targets. To the extent that specific law enforcement policies reinforce the magnitude of inequality in the personal distribution of income in the population, this could be used as a mechanism to compensate for the harm caused by income inequality. Miceli (1991) discusses the sense of justice that permeates the application of severe penalties. The author suggests that society derives some use in punishing those who are truly guilty and the wrong condemnation of innocent people, or the acquittal of guilty persons, impose costs on society (Type I and II errors). For higher sentences it is expected a higher amount of certainty about the culpability of the defendant. And Mitchell Polinski and Shavell (2000) suggest that the utility of individuals dependent on penalties imposed on those who violate the laws. Specifically, individuals obtain what the authors call fairness-related utility (or disutility) from the imposition of penalties on others. In the existence of this fairness-related utility, the desired level of deterrence changes, since the total damage caused by a criminal action starts to include the utility or disadvantage associated with the imposition of penalties on criminals.

A final discussion, still about conceptions of justice within the Economic Theory of Crime, is the use of the comparative fault system as a means of achieving efficiency and justice. Harel (1994) argues that Criminal Law is designed only to in- 
fluence the behavior of criminals, when the behavior of both criminals and victims would be influenced by the incentives derived from Criminal Law. Failure to include victims as agents whose behavior must be influenced by criminal law creates distributive inefficiency for two reasons: i) for not creating the necessary incentives for taking individual precautions; and ii) for making sure that those who prevent themselves have to bear the costs of neglecting others. Efficiency requires the distribution of precautionary costs between the State and potential victims so that the total cost of crime is minimized.

Two models of Criminal Distributive Justice are proposed by Harel (1994), the egalitarian protection model and the egalitarian cost model. The first requires that the criminal system provide each individual with the same level of protection against crime, with the level of protection calculated by the damage expected by the crime for each individual. The second, on the other hand, requires the State to invest an equal amount of resources in the protection of each individual.

The egalitarian protection model focuses on the results of the criminal system (protection offered), while the egalitarian cost model focuses on the resources involved in the criminal system. To apply an egalitarian protection model, extra protection is needed for those individuals most vulnerable to crimes, in order to equate their expected damage to that of the least vulnerable individuals. For Harel (1994) it is reasonable applying this model when the extra vulnerability of potential victims is not voluntary (for example, women are more vulnerable to sexual crimes and minorities are vulnerable to hate crimes). "The equal protection model is appropriate when the harm is predominantly the byproduct of an involuntary vulnerability, although the involuntary vulnerability may be coupled with a voluntary act" (Harel, 1994: p. 1205).

Under the egalitarian cost model, it is unfair that some individuals are given more resources for their protection even if these individuals are more vulnerable to crime without these additional resources. This model is the most efficient when negligent victims voluntarily contribute to their respective vulnerability, imposing higher ex ante costs on the criminal system. Equalizing protection costs requires that less effort be invested in protecting negligent victims than those invested in protecting prevented victims. This can be done either by imposing milder penalties on criminals who have acted on negligent victims, or by reducing the resources devoted to investigating and prosecuting these criminals. It is within the logic of the egalitarian cost model that the comparative fault system is best applied (Harel, 1994: pp. 1207-1208).

The final question we would like to address in this section is: should justice system be based in allocative efficiency? Ehrlich (1982: p. 7) raises some implications of a justice system whose main goal is allocative efficiency. First, an enforcement policy whose objective is to maximize income generally calls for the introduction of some differentiation rather than the degree of protection provided to different groups of the population, depending on the potential individual loss from crimes and the high price of providing individual protection; and 
second, it can be optimal for law enforcement to impose discriminatory penalties and define different probabilities of apprehension for different groups of criminals, depending on how much they respond to changes in these deterrent instruments, or how high their rates of participation in crime are.

For the first implication, it can be expected that the enforcement agency would place a greater emphasis on protecting the wealthier since the real loss of income caused by the victimization of these groups tends to be greater and the cost of providing protection in neighborhoods affluent is, on average, smaller (the residents of these neighborhoods themselves have incentives to spend on self-protection). However, such a policy would conflict with the principle of equal protection over the law (Ehrlich, 1982: p. 8).

Conversely, for a group of individuals who have the same characteristics-for example a group of criminals who inflict equal social harm through equal crimes, which are equally costly to be apprehended and whose responses to severity and probability of apprehension are identical-any enforcement policy that allows for unequal treatment of these criminals will be socially inefficient, as it would create systematic differences in marginal benefits in law enforcement in individual cases where the underlying costs and benefits are identical (Ehrlich, 1982: p. 9). Therefore, under a criterion of justice as efficiency, it is conceivable the existence of discrimination between groups of different characteristics (incentives), the same cannot be said when we analyze individuals from the same group.

One concern of optimum law enforcement models is to avoid both under and overdeterrence. Underdeterrence is a desirable situation to avoid, since it would imply in more crimes than the amount spent in enforcement should prevent. The same cannot be said about overdeterrence. Because society has refused on moral grounds to recognize the existence of criminal benefits, criminal law has little reasons to fear overdeterrence (Coffee Jr., 1991: p. 195).

Furthermore, it is not certain that society desires the justice system to be oriented towards allocative efficiency. Sunstein, Schkade, and Kahneman (2000) found that individuals reject the idea of law enforcement policies being designed to achieve optimum deterrence.

\section{A Positive-Normative Analysis of Economic Theory of Crime}

In this section, the three topics presented in the previous section are analyzed from the perspective of the positive-normative dichotomy of Law and Economics. Given that the main distinction between normative and positive economics it is on the presence of moral questions inside economics as an independent scientific field, analyzing how those three previous topics are addressed by normative and positive Law and Economics can provide us a better understanding of the economists approach to a non-economic problem such as criminality. In the first subsection, we briefly present the distinction between positive and nor- 
mative economics within economics. The option to present this subsection, as it becomes clearer in Subsection 3.2, is due the fact that positive-normative distinction in Law and Economics is not quiet the same as the distinction in economics. In the second subsection, the positive-normative distinction in Law and Economics is presented and also used to analyze those three topics previously presented.

\subsection{Positive-Normative Distinction in Economics}

According to Hausman and McPherson (2006: p. 60): "Positive economics is concerned with the explanation and prediction of economic phenomena, while normative economics is concerned with evaluating economic policies, and states of affairs from a moral standpoint."

The positive economy consists of unethical "true-or-false" claims about economic science or aspects of the economy. It also includes empirical statements and conclusions derived from hypothetical arguments (Weston, 1994: p. 4). In turn, normative economics consists of propositions related to economics that contain at least one statement about what is ethically preferable (Weston, 1994: p. 5).

The positive economy appears in a historical context in which economic science sought to "emancipate" from its utilitarian past, such that economists from this period sought to develop a pure science, free from ethical and moral issues. However, what is currently known as positive economics are the definitions proposed by Friedman (1953) in his article "The Methodology of Positive Economics". For Friedman, the positive approach to economics consists of a set of axioms whose correspondence to reality is unnecessary, but which, based on logical deduction, is capable of generating empirically testable hypotheses. Furthermore, theories are evaluated based on their ability to generate predictions and their simplicity.

On the contrary, normative economics it is often associated with social welfare studies. Initially, such studies were based in the idea of interpersonal comparisons of utility, a concept very present in the economics before the ordinalist victory in the debate against cardinalists.

As Wade Hands (2012) highlights, as economic science moved away from the interpersonal comparison of utility in the late 1930s and early 1940s, the criteria for evaluating utilitarian policies (total or average maximization of utility) was replaced by the criteria proposed by Pareto:

Economists embraced the change to the Pareto criteria in welfare economics primarily because it offered an evaluative standard that was of all of the troublesome normative issues associated with interpersonal comparisons of utility and thus provided a strictly positive/scientific way of making judgments about social welfare and microeconomic policy (Wade Hands, 2012: p. 7).

Given that Pareto efficiency is entirely based on satisfying the preferences of 
economic agents, i.e., making them better or worse, there is an implicit idea that the search for satisfying preferences is good (desirable). This value-free definition based on economic efficiency allows economists to conclude that perfect competitive balances are morally desirable and market imperfections, which interfere in achieving competitive balance, are morally undesirable.

In essence, the positive approach to economics emphasizes the use of economic tools, especially microeconomics, for the construction of hypotheses that are subject to empirical testing. It is based on the assumption of agents rationality and then, it is verified whether it is compatible with the reality it seeks to explain. Conversely, the normative approach uses the same microeconomic tool as a method for proposing policies, in which the objective is to achieve efficiency in the sense of Pareto.

A different thinking about the rational choice theory, a view that is usually used by philosophers, particularly philosophers of the theory of choice, is a sort of specific type of normative theory, a normative theory of rationality (Wade Hands, 2012: p. 11). The rational choice theory would be a normative theory in the sense of theorizing what an individual ought to do in order for his behavior be considered rational. In this sense, the normative of the rational choice theory does not imply that the theory needs to address ethical issues. For Hausman (2006: p. 64): "Rationality is a normative notion. One ought to be a rational; one is foolish or mistaken if one is not rational. But it might reasonably be contended that rationality is not a moral notion."

According to this philosophical interpretation, the "traditional" approaches to positive and normative economics would both be considered normative. The first because represents a criteria of how individuals ought to behave in order to be rational, but failing to be a descriptive theory of individual behavior. And the second for stating that among two situations, $\mathrm{X}$ and $\mathrm{Y}$, if the first leaves individuals better (in the sense of Pareto) compared to the second, so this must be the situation that society must seek to achieve.

Besides the positive/normative distinction, there is another distinction, between values and facts, in economic methodology (Heath, 1994). In this perspective, values differ from facts because the former is ultimately a matter of subjective opinion, i.e., cannot be tested in any objective sense. That is why normative economics statements cannot be tested, since their validity rests on value judgments.

Positive economics avoids discussions about individuals tastes and values, arguing that those are empirically untestable. However, since it is undeniable that both (tastes and values) are crucial in individuals decision making, positive economics simply assume that tastes and values are incorporated inside individuals ordering preferences.

Methodologically, value judgments can be separated as methodological value judgments (henceforth MVJs) and ethical value judgments (henceforth EVJs). According to Silvestri (2009): 
On the one hand, MVJs, are those judgments that enter into the picture every time a scholar/scientist tries to answer the question of how one ought to carry out one's investigations. They are interpretations and/or choices of premises, theories, inferences, and data, that rely on our commitment to particular methodological values. Methodological values include simplicity, predictive power, external and internal consistency, empirical adequacy, accuracy, and so on. On the other hand, EVJs are judgments on what is morally right or wrong (Silvestri, 2009: p. 8).

This distinction is usually based on the idea that MVJs are widely accepted by the scientific community, while EVJs are the source of endless discussions.

MVJs are widely used in positive economics since it accepts the exclusion of tastes, moral values and other individuals intrinsic caracteristics simply because they make it difficult to create models capable of empirical testing. On the other hand, EVJs assumes that those variables (tastes and values) are indispensable in order to make a correct analysis of reality.

In choosing between MVJs or EVJs, the economist is faced with the following problem: should tastes and values be neglected in order to (models) achieve empirical adequacy; or should tastes and values be considered so a greater description of reality is achieved?

Calabresi (2016: p. 152) offers one possible answer: "how costly is the exclusion of some values and tastes from the model depends on the questions that is being asked; the issue that is being analyzed."

We tend to agree with Calabresi's position. The object to be analyzed generates a huge influence on the need to take into account moral aspects. Specifically, Economic Theory of Crime, as a subject belonging to Law and Economics, raises very vividly those moral issues, as discussed in previous chapter, and therefore deserves a particular analysis, as we propose on next section.

\subsection{Positive-Normative Distinction and Economic Theory of Crime}

Within Law and Economics' literature there is also a distinction between positive and normative schools of thoughts. The positive approach to economic analysis of law is associated with the University of Chicago, whose foundations can be found in Richard Posner's publications throughout the 1970s. The Chicago's approach to Law and Economics follows the idea that common law results in strong efforts to induce efficient results. Such a premise is known as the common law efficiency hypothesis. Common law rules seek to allocate resources in such a way that Pareto or Kaldor-Hick efficiency is achieved. Chicago scholars recognize from the outset that economists' competence in evaluating legal issues is limited. If, on the one hand, economic prospects may prove crucial for a positive analysis of the efficiency of different legal rules and for studying the effects of these different legal rules on the distribution of income, Chicago economists also recognize the limits of their role as providers of normative prescriptions for 
social change and legal reforms (Parisi, 2004: p. 264).

The normative approach to economic analysis of law, in turn, is associated with the University of Yale, whose main belief is the need for major legal intervention as a way to correct market failures. Distributive concerns are central to Yale scholars. Given the predominant need to seek justice through the legal system, most Yale scholars would suggest that efficiency could never be the ultimate goal of the legal system (Parisi, 2004).

Normative economics, or welfare economics, is concerned with the objectives of allocative efficiency, with the identification of situations in which efficiency is not achieved and in the prescription of corrective solutions. For Veljanovski (1980):

Welfare economics as a prescriptive tool is based on the concept of market failure. When the assumptions underlying the perfectly competitive market are not met the market will either operate inefficiently or fail to exist. This departure from the ideal outcome of the perfectly competitive market is referred to as market failure and is a necessary efficiency condition for legal intervention. It is not a sufficient condition because the costs of intervention, both direct and as a consequence of other misallocations it gives rise to, may outweigh any efficiency gains (Veljanovski, 1980: p. 169).

The normative approach to allocative efficiency in law making, usually states that the purpose of the laws is to minimize the social costs of an activity, providing incentives to deter non-economic losses.

One important distinction between welfare economics and pure Pareto efficiency is that the former is concerned with distributive aspects, while the latter is not. Even though Pareto criteria accepts subjectiviness in individuals utility function, there is no value judgment on whether those subject values should be. Conversely, welfare criteria defends that redistribution is a goal along with efficiency (Cooter, 1989).

Posner (1979: p. 112) criticizes the welfare economy, and the whole concept of utility maximization, as he understands that this approach has failed to emancipate itself from some crucial dilemmas of utilitarianism, for example, that the domain of utilitarianism is uncertain. Specifically, Posner argues that it is not clear which factors are considered in the calculation of happiness or satisfaction of individuals' preferences, in addition to which individuals must have their respective happiness/satisfaction included in the calculation of social welfare. Although Posner (1979) recognizes that paretian welfare economics succeeded, in part, in solving the problem of measuring satisfaction. This approach, however, does not solve the need for a dependent metric, even if it is accepted that a market transaction increases the happiness/satisfaction of the agents, in comparison to the situation immediately prior to the transaction.

Given this dissatisfaction with the welfare maximizing approach, Posner suggests that the variable to be maximized in the economic analysis of law is wealth. Posner (1979) defines wealth as the value in dollars or in monetary equivalents 
of everything in society. It is measured by how much people are willing to pay for something or, if they already own the good, how much money they demand to give it up.

The problem of the uncertain domain in utilitarian approaches is solved by substituting utility for wealth, since not only can wealth not be equated with happiness, but individuals are not purely wealth maximizers (wealth represents only one of the goods inside an individual preferences). That way, using wealth as criteria narrows the domain of economic analysis to a variable not dependent on subjective matters.

There are two objections made against wealth maximization. The first relates to the need for specifying an initial set of entitlements or rights as a necessary prerequisite for operationalizing wealth maximization. This line of critique argues that rights have values and those must be accounted in terms of how useful they might be to the accumulation of wealth (Parisi \& Klick, 2004: p. 443). Second, relates to the difficulty of defining the proper role of efficiency as an ingredient of justice, compared to other social goals. The question is whether wealth is the ultimate goal of justice system or if wealth is just a mean towards others ends, as utility or equality (Parisi \& Klick, 2004: p. 444).

Veljanovski (1980) disagree with this classification of the Chicago approach as positive. Following an interpretation more related to philosophers, he argues that Posner's exclusive concentration on the concept of efficiency has clear normative connotations. There is, implicitly, in his defense of efficiency the idea that it is desirable, or of high interest, to society:

While the economist may be able to contribute more to discussions of efficiency this does not justify or support the suppression of the ethical basis and implications of legal decisions, and one of his tasks should be to make these clear. If there is a conflict between efficiency and justice the nature of the tradeoffs can be illuminated by economic analysis, and since the attainment of justice usually involves the use of scarce resources the economic approach can contribute to normative discussions by providing information on the cost of justice (Veljanovski, 1980: p. 178).

Have made this short introduction about the distinction between positive and normative in Law and Economics, we direct our analysis to Economic Theory of Crime. In doing so, we hope to answer those three topics raised in the previous chapter.

The first topic we address is the purpose of criminal justice. The purpose of Criminal Law, under the normative economics approach, is to impose additional costs on conduct classified as illegal, with the objective of limiting this conduct to efficient levels. Oppositely, the positive approach to criminal behavior is not concerned with efficiency issues in Criminal Law, but with the way in which criminal behavior responds to changes in the expected costs and benefits of crime (Rowley, 1981: p. 395-396).

When we think about Criminal Law, Posner (1979) criticism of "what utilities 
should be taken into account in a social welfare analysis" is very relevant. Under prescriptive analysis, it is highly questionable that society takes criminal earnings into account in a hypothetical calculation of social welfare, and descriptively, lawyers and legislators do not appear to take these gains into account when prescribing and enforcing laws (unless applicable) the principle of insignificance.

Following this line, Coffee Jr. (1991) argues:

Once it is recognized that society generally intends to prohibit behavior through the criminal law, it follows that there cannot be an "optimal" rate of crime that is to be attained by pricing the subject behavior. [...] only enforcement costs justify allowing the "optimal" rate of crime to exceed zero (Coffee Jr., 1991: p. 194).

His position clearly favors a positive analysis of Criminal Law instead of a normative one, since the former only takes into account the costs of law enforcement, i.e., marginal costs should equal marginal harm, and optimality is achieved when the cost to prevent further crimes exceeds the harms imposed by those crimes.

This approach is reasonable when applied to commensurable crimes, as theft and burglary, but can we say the same for crimes like murderer? What is the marginal harm caused by an extra murder to be compared with the marginal cost of enforcement? Additionally, if we consider that a social welfare function, for either positive or normative approaches, is constructed adding all individuals utility functions, the one who is being murdered was an infinite loss and no Kaldor-Hicks optimality could be achieved since no benefit could compensate his lost.

As demonstrated by the works of Ehrlich (1982), Miceli (1991), and Mitchell Polinski and Shavell (2000), it is possible to incorporate moral values such as fairness into economic models of optimal law enforcement. These models show the possibility of economists to consider more than just deterrence as an end of justice system through a positive analysis, in which the social value (fairness) is incorporated to social welfare function, and the consequences of this social choice can be evaluated. However, those models remain tied to the justice as efficiency dilemma.

One clear problem of adopting justice as efficiency can be seen in Mitchell Polinski and Shavell (1984) conclusions. The authors argue that non monetary sanctions (such as imprisonment) should only be applied to low income individuals, because monetary sanctions that exceed their income would have no deterrent effect. This conclusion clearly violates some basic principles of democratic societies, especially that each individual should be treated equally under the law, mostly because monetary and non monetary sanctions are not viewed as substitutes. Therefore, if a rich individual commits a crime and is condemned to pay a fine, while a poor one is condemned to prison (because cannot afford the fine) for commiting the same crime, society would not conceive as "equality under the law", even though efficiency is achieved this way. 
On the punishment as deterrence topic, Robinson and Darley (2004) points out the existence of some prerequisites to Criminal Law really deter individuals. First, potential offenders must have knowledge of the law. This does not mean a deep legal knowledge, but if Criminal Law is designed to deter, as positive approach claims, is necessary that individuals do have legal knowledge otherwise fear of punishment will not hold them back. For a normative perspective, where both over and underdeterrence is conceived, legal knowledge is even more necessary, because without full appraisal of costs, individuals cannot act rationally and both over and underdeterrence can occur.

Second, if Criminal Law intents to deter, potential offenders must be motivated to change his behavior because of the law. This means that punishment must be perceived as a cost. To Robinson and Darley (2004), perceiving criminal system punishments as costs is context dependent and sensitive to particular interpretations. When offenders act in groups, for instance, individuals seems to act giving less weight to consequences compared to a rational individual. Some sociological theories, argue that inside deviant groups, having a "criminal label" may be beneficial to the individual (as opposed to be predicted by Economic Theory of Crime). A theory that does not take in account values would consider such a behavior as irrational.

Punishment commensurability is another debate in which positive-normative analysis can shed some light on. Under wealth maximization perspective, only the forgone earning that an offender losses when become an inmate (both the incapacitation time and the lower income caused by the criminal record can be taken in account) are considered, and for that reason the sanction versus fine comparison becomes feasible. Under a utility maximization perspective, others non monetary costs such as deprivation of freedom, worst living conditions and others are, at least theoretically, taken into account. This approach allows further research agenda such as intertemporal inconsistency, which has important contributions to deterrence literature.

Our final topic, morality, is perhaps the richer of all to explore under the lens of positive-normative methodology. First of all, because morality is a value on its own, and one of the reason economists departed from cardinal utilities to ordinal ones, was to avoid entering in those ethical grounds. However, when discussing about criminal behavior and criminal justice it is almost impossible to not bring the morality question to the table. So, we bring back the inquiry: should criminal gains be considered a positive gain to social welfare? Starting from Becker (1968) to most of all theoretical authors in economics of crime, all considered the benefits of crime positively in the calculus of social welfare. This happened because since the beginning the aim was to built a general theory of illegal behavior and law enforcement.

The general crime theory proposed by economists faces an empirical inadequacy: the separation of law in two spheres (Tort Law and Criminal Law). As previously exposed, some authors defends that this distinction exists on moral grounds, i.e., tortious offenses constitutes violations of private interests, while 
criminal ones represent a violation of social norms. Even though some economists accept the basis of this distinction, it is quiet complicated (for economists) to make this separation, because social welfare function is constructed aggregating individuals utilities, making difficult to separate between an individual harm (a tort offense) and a social harm (a criminal offense).

A good example of how difficult is for economists to incorporate social values into models is through the definition of public goods. The technical feature of a public good is that it cannot, or is very costly, be parceled out to different consumers in different quantities:

The value of public goods, as understood by economists, is the individual satisfaction afforded by them, just as with a private good. [...] Public goods are, consequently, distinguished from private goods by technical characteristics of their supply (non-exclusion and non-rivalry), not by non-individual values (Cooter, 1989: p. 825).

According to Posner (1997), the main interaction between social norms and laws is through the reduction (or increase) in compliance costs. Laws that reflect existing social norms are less costly to enforce. In Law, this distinction is known as malum prohibitum and malum in se. Crimes perceived as malum in se violates more than just the legal code, but also social conventions, and individuals do not commit those offenses because they are affraid of both legal treat and social rejection. Conversely, crimes that are perceived as malum prohibitum are more costly to enforce because some individuals might not perceive their acts as wrong or immoral and therefore do not suffer constraints from social circles, although the act is forbidden by the law.

The tort law and criminal law division can also be applied to the malum prohibitum and malum in se distinction. Crimes of the former category should be inside civil sphere (Tort Laws), while the latter should be inside criminal sphere (Coffee Jr., 1991). If it is true that criminal law helps internalizing social norms, is important that criminal law only encompass malum in se crimes, otherwise the morality that separates both categories will no longer stand and criminal law will not be able to sustain its educational goal.

Moral values are a subject hard to be kept away from criminal debate. And should not. Likewise fairness, it is possible to incorporate social norms into economic models. To not follow a social norm can be costly to an individual, because society (or at least his social circles) may impose some sort of retaliations, like shamming or ostracism, or can be beneficial when following the norms helps someone to socialize or fit in. As Lessig (1996) recalls, this approach to social norms is appropriate to economics for maintaining methodological individualism and self-centered individuals assumption, which makes it feasible to be incorporated in a standard utility maximization problem.

The positive and normative Economic Theory of Crime presents substantial methodological differences that imply different conclusions, especially when topics such as morality and a sense of justice, which have historically been avoided 
within traditional economics, are brought up for debate. However, as we see it, both fail to provide a complete theory for criminal behavior and law enforcement. From the normative perspective, the main problem is the open domain that utility maximization bring, i.e., there is no limitation on what is to be considered a social gain or lost. This is problematic since gains obtained through criminal violations are not viewed, by society, as a social benefit and, therefore, the theory fails to represent reality. From the positive perspective, imposing that wealth should be the only criteria for law enforcement policies is also problematic. First, because it imposes the necessity to convert all types of costs and benefits into monetary values, which brings difficulty when applied to hideous crimes. Second, is debatable if imposing that wealth is the best measure for Law and Economics theories (Economic Theory of Crime included) is truly a positive approach. That is, although wealth maximization could bring the best outcomes for law enforcement policies, it is not clear that society desires criminal law to be based on wealth maximization criteria. Therefore, likewise the normative perspective, we consider that the positive perspective also fails to represent reality (even though it states to be a positive theory).

\section{Final Remarks}

Throughout this paper we have presented some existing methodological debates in Economic Theory of Crime and discussed how these issues are treated from the perspective of the positive-normative dichotomy in economics. Normative Law and Economics aims to prescript how law and public policy should be designed for the purpose of enhancing social welfare. Inside this approach, the main goal of policy makers is to design policies that increase the amount of utility in society. Values are considered in individuals utilities, but since those are hard to verify (empirically) they are taken as given. On the other hand, positive Law and Economics aims to predict alternative ways of action, i.e., what will be the outcome of different possible policies options. It also avoids giving prescriptions. Those scholars that follow positive analysis believe that the goals society should pursuit are to be politically determined, therefore outside of economic inquiry.

Two discussions can be drawn from this assertion. First, economics has traditionally placed itself as a policy prescribing science. To recommend one policy instead of another, even if justified on an efficiency basis, has a normative connotation. This value-free position economics places itself contradicts its claim to be a proponent of public policies, especially when these policies are linked to moral issues such as criminality. If criminal justice should be designed to maximize social welfare (which is the sum of all individuals utility) considering criminal gains as welfare enhancing is not value free. Likewise, to assume that sanctions can be equated to harms, especially when both are non-monetary, and construct cost-benefit analysis based on it is not value free.

Second, is concerned with the methodological choice of placing tastes and values as exogenous variables. Obviously, it is impossible for the economist to 
read an individual mind and discover what tastes and values he shares. But not all values are individually determined. Some values are socially shaped and, therefore, can be identified by analyzing aggregate patterns. If tort law and criminal law are distinguished by moral values, an economic theory that aims to study illegal behavior cannot take values exogenously. Additionally, if it is acceptable that some individuals might derive some sort of utility from committing crimes as murder or rape (which are socially considered as hideous), it should also be acceptable for economists to take a position against it.

We also believe that analyzing the Economic Theory of Crime through the lens of positive-normative analysis helps us to elucidate the way in which other disciplines that have criminality as a subject of study, interpret economic contributions. One example is how law scholars evaluate economics contributions.

For Veljanovski (1980) Economic Theory of Crime has been used, mostly, as predictive science. However, even with empirically relevant results, economic analyzes have had little impact on the way in which jurists think about Criminal Law, for two main reasons. First, the main question debated by economists-are legal punishments capable of deterring crimes?-it is not something that is considered relevant, by jurists, with regard to the operationalization of the criminal justice system, or in the legal issues surrounding the treatment of criminals and the processes of Criminal Law. Second, the economic literature on crime is about law enforcement and deterrence, not law itself.

Analyzes that opt for the positive approach (prediction) have greater acceptance of other disciplines when the crimes studied are pecuniary or easily monetized. In turn, the analyzes that follow the normative approach (prescription) touches on issues such as the presence of morality in the decision of individuals and what should be the objective of the justice system and, because those are unsettled debates either in economics or in outside disciplines, tend to be less accepted. However, we believe that Economic Theory of Crime should treat separately Criminal Law and Tort Law. Specifically, wealth maximization criteria (positive analysis) could be used on tort crimes analysis, since those are easily converted into monetary values and mostly do not depend on moral debates. On the other hand, criminal law cannot be disassociated from moral issues and, therefore, the normative approach is more indicated for these cases. However, if the theory wants to reflect the reality it tries to explain, some restrictions should be imposed upon the domains of the social welfare function, i.e., the sorts of utility gains derived from criminal activity should be restricted to better reflect society views about criminal behavior.

\section{Conflicts of Interest}

The authors declare no conflicts of interest regarding the publication of this paper.

\section{References}

Andenaes, J. (1970). The Morality of Deterrence. The University of Chicago Law Review, 37, 649-664. https://doi.org/10.2307/1598839 
Barnes, W. (1988). Revenge on Utilitarianism: Renouncing a Comprehensive Economic Theory of Crime and Punishment. Indiana Law Journal, 74, Article No. 5.

Becker, G. (1968). Crime and Punishment: An Economic Approach. Journal of Political Economy, 76, 169-217. https://doi.org/10.1086/259394

Bittner, E., \& Platt, A. (1966). The Meaning of Punishment. Issues Criminology, 2, 79-99.

Calabresi, G. (2016). The Future of Law and Economics: Essays in Reform and Recollection. Yale University Press. https://doi.org/10.12987/yale/9780300195897.001.0001

Calabresi, G., \& Melamed, A. D. (1972). Property Rules, Liability Rules, and Inalienability: One View of the Cathedral. Harvard Law Review, 85, 1089-1128. https://doi.org/10.2307/1340059

Coffee Jr, J. C. (1991). Does Unlawful Mean Criminal: Reflections on the Disappearing Tort/Crime Distinction in American Law. Boston University Law Review, 71, 193-246.

Cooter, R. (1984). Prices and Sanctions. Columbia Law Review, 84, 1523-1560. https://doi.org/10.2307/1122472

Cooter, R. (1989). Best Right Laws: Value Foundations of the Economic Analysis of Law. Notre Dame Law Review, 64, 817-837.

Dau-Schmidt, K. G. (1990). An Economic Analysis of the Criminal Law as a Preference-Shaping Policy. Duke Law Journal, 1990, 1-38. https://doi.org/10.2307/1372651

Drane, R. W., \& Neal, D. J. (1980). On Moral Justifications for the Tort/Crime Distinction. California Law Review, 68, 398-421. https://doi.org/10.2307/3479992

Ehrlich, I. (1982). The Optimum Enforcement of laws and the Concept of Justice: A Positive Analysis. International Review of Law and Economics, 2, 3-27. https://doi.org/10.1016/0144-8188(82)90011-4

Friedman, M. (1953). The Methodology of Positive Economics. In U. Mäki (Ed.), The Methodology of Positive Economics: Reflections on the Milton Friedman Legacy (p. 3-43). Cambridge University Press. https://doi.org/10.1017/CBO9780511581427.002

Garoupa, N. (1997). The Theory of Optimal Law Enforcement. Journal of Economic Surveys, 11, 267-295. https://doi.org/10.1111/1467-6419.00034

Gibbons, T. (1982). The Utility of Economic Analysis of Crime. International Review of Law and Economics, 2, 173-191. https://doi.org/10.1016/0144-8188(82)90004-7

Harel, A. (1994). Efficiency and Fairness in Criminal Law: The Case for a Criminal Law Principle of Comparative Fault. California Law Review, 82, 1181-1229. https://doi.org/10.2307/3480909

Hausman, D., \& McPherson, M. (2006). Economic Analysis, Moral Philosophy and Public Policy (2nd ed.). Cambridge University Press.

https://doi.org/10.1017/CBO9780511754289

Heath, W. C. (1994). Value Judgments and the Principles of Economics Textbook. Southern Economic Journal, 60, 1060-1064. https://doi.org/10.2307/1060443

Klevorick, A. K. (1985). Legal Theory and the Economic Analysis of Torts and crimes. Columbia Law Review, 85, 905-920. https://doi.org/10.2307/1122456

Lessig, L. (1996). Social Meaning and Social Norms. University of Pennsylvania Law Review, 144, 2181-2189. https://doi.org/10.2307/3312651

McChesney, F. (1993). Boxed in: Economists and Benefits from Crime. International Review of Law and Economics, 13, 225-231.

https://doi.org/10.1016/0144-8188(93)90008-S

McCloskey, H. (1965). A Non-Utilitarian Approach to Punishment. Inquiry, 8, 249-263. https://doi.org/10.1080/00201746508601433 
Miceli, T. (1991). Optimal Criminal Procedure: Fairness and Deterrence. International Review of Law and Economics, 11, 3-10. https://doi.org/10.1016/0144-8188(91)90022-6

Mitchell Polinski, A., \& Shavell, S. (1984). The Optimal Use of Fines and Imprisonment. Journal of Public Economics, 24, 89-99. https://doi.org/10.1016/0047-2727(84)90006-9

Mitchell Polinski, A., \& Shavell, S. (2000). The Fairness of Sanctions: Some Implications for Optimal Enforcement Policy. American Law and Economics Review, 2, 223-237. https://doi.org/10.1093/aler/2.2.223

Parisi, F. (2004). Positive, Normative, and Functional Schools in Law and Economics. European Journal of Law and Economics, 18, 259-272. https://doi.org/10.1007/s10657-004-4273-2

Parisi, F., \& Klick, J. (2004). Functional Law and Economics: The Search for Value-Neutral Principles of Lawmaking. Chi-Kent Law Review, 79, 431-450. https://doi.org/10.2139/ssrn.441941

Posner, R. A. (1979). Utilitarianism, Economics, and Legal Theory. The Journal of Legal Studies, 8, 103-140. https://doi.org/10.1086/467603

Posner, R. A. (1980). The Ethical and Political Basis of the Efficiency Norm in Common Law Adjudication. Hofstra Law Review, 8, 487-507.

Posner, R. A. (1985). An Economic Theory of the Criminal Law. Columbia Law Review, 85, 1193-1231. https://doi.org/10.2307/1122392

Posner, R. A. (1997). Social Norms and the Law: An Economic Approach. American Economic Review, 87, 365-369.

Robinson, P. H., \& Darley, J. M. (2004). Does Criminal Law Deter? A Behavioral Science Investigation. Oxford Journal of Legal Studies, 24, 173-205.

https://doi.org/10.1093/ojls/24.2.173

Rowley, C. (1981). Social Sciences and Law: The Relevance of Economic Theories. Oxford Journal of Legal Studies, 1, 391-405. https://doi.org/10.1093/ojls/1.3.391

Silvestri, P. (2019). On the Future of Law and Economics: The Uneasy Burden of Value Judgments. Global Jurist, 19, Article ID: 20190026.

https://doi.org/10.1515/gj-2019-0026

Stigler, G. (1970). The Optimum Enforcement of Laws. Journal of Political Economy, 78, 526-536. https://doi.org/10.1086/259646

Stigler, G. J., \& Becker, G. S. (1977). De Gustibus Non Est Disputandum. The American Economic Review, 67, 76-90.

Sunstein, C., Schkade, D., \& Kahneman, D. (2000). Do People Want Optimal Deterrence? Journal of Legal Studies, 29, 237-253. https://doi.org/10.1086/468069

Veljanovski, C. (1980). The Economic Approach to Law: A Critical Introduction. British Journal of Law and Society, 7, 158-193. https://doi.org/10.2307/1409659

Wade Hands, D. (2012). The Positive-Normative Dichotomy and Economics. In U. Mäki (Ed.), Philosophy of Economics: Handbook of the Philosophy of Science (pp. 219-239). North Holland. https://doi.org/10.1016/B978-0-444-51676-3.50009-9

Weston, S. (1994). Toward a Better Understanding of the Positive/Normative Distinction in Economics. Economics \& Philosophy, 10, 1-17.

https://doi.org/10.1017/S0266267100001681 